\title{
PENGEMBANGAN INSTRUMEN ASESMEN KETERAMPILAN BELAJAR DAN BERINOVASI PADA MATA PELAJARAN IPA SD
}

\author{
P. Eka Sastrika Ayu ${ }^{1}$, A. A. I. N. Marhaeni ${ }^{2}$, P. Budi Adnyana ${ }^{3}$ \\ Program Studi Pendidikan Dasar, Program Pascasarjana \\ Universitas Pendidikan Ganesha \\ Singaraja, Indonesia
}

e-mail: \{sastrika.ayu1, agung.marhaeni, budi.adnyana \}@pasca.undiksha.ac.id.

\begin{abstract}
Abstrak
Penelitian ini bertujuan untuk (1) mengetahui kebutuhan terhadap instrumen asesmen keterampilan belajar dan berinovasi pada mata pelajaran IPA SD. (2) mengetahui design instrumen asesmen keterampilan belajar dan berinovasi pada mata pelajaran IPA SD. (3) mengetahui kualitas instrumen asesmen keterampilan belajar dan berinovasi pada mata pelajaran IPA SD hasil pengembangan dari aspek validitas, reliabilitas dan kepraktisan. Jenis penelitian yang digunakan dalam penelitian ini merupakan penelitian pengembangan yang diadaptasi dari model 4-D yang dikembangkan oleh Thiagarajan (1974). Pengembangannya terdiri dari empat tahap yaitu define, design, develop dan disseminate. Penelitian ini dilaksanakan di seluruh sekolah dasar gugus 6 Kecamatan Banjar Buleleng Bali. Hasil penelitian menunjukkan bahwa: (1) instrumen keterampilan belajar dan berinovasi sangat dibutuhkan oleh siswa SD. Hal ini dikarenakan kegiatan asesmen sangat penting dalam pembelajaran untuk mengetahui sejauh mana keterampilan belajar dan berinovasi peserta didik, (2) design instrumen asesmen keterampilan belajar dan berinovasi pada mata pelajaran IPA SD mengacu pada kriteria secara kualitatif maupun secara kuantitatif. Ketrampilan berpikir kritis, pemecahan msalah dan kreativitas siswa berupa tes uraian, sedangkan keterampilan berkomunikasi dan keterampilan berkolaborasi berupa lembar observasi, (3) kualitas Instrumen asesmen keterampilan belajar dan berinovasi pada mata pelajaran IPA SD hasil pengembangan sudah memenuhi dari aspek validitas, reliabilitas dan kepraktisan.

Kata-kata kunci: pengembangan instrumen asesmen, keterampilan belajar dan berinovasi
\end{abstract}

\section{Abstract}

This research aimed to (1) know the need for the instrument assessment of learning skills and innovating on the subjects of science in Elementary School. (2) Know the design of instruments of learning skills assessment and innovating in science in Elementary School. (3) Know the quality of the instrument assessment of learning skills and innovating on the subject of science in Elementary School development from the aspect of validity, reliability and practicality. The type of research used in this study is an adapted development study of the 4-D model developed by Thiagarajan (1974). The development consists of four stages, namely define, design, develop and disseminate. This research was conducted in all of the primary schools of Group 6 in Banjar Buleleng Bali. The results showed that: (1) Instruments of learning skills and innovating are needed by elementary students. This is because the assessment activity is very important in learning to know the extent of learning and innovating skills students, (2) The design of instruments of learning skills and innovating on the subjects of science in Elementary School refers to the criteria qualitatively and quantitatively. Critical thinking skills, problem solving and student creativity in the form of a description test, while communicating skills and collaborating skills in the form of an observation sheet, (3) The quality of the instrument assessment of learning skills and innovating on science in Elementary School development has fulfilled the aspects of validity, reliability and practicality.

Key words: development of assessment instruments, learning and innovation skills 


\section{PENDAHULUAN}

Industri 4.0 sebagai fase revolusi teknologi mengubah cara beraktifitas manusia dalam skala, ruang lingkup, kompleksitas, dan transformasi dari pengalaman hidup sebelumnya. Manusia bahkan akan hidup dalam ketidakpastian (uncertainty) global, oleh karena itu manusia harus memiliki kemampuan untuk memprediksi masa depan yang berubah sangat cepat.

Pemerintah berupaya merespon tantangan industri 4.0, dengan meningkatkan kualitas sumber daya manusia melalui pendidikan di tahun 2018. Pemerintah melalui kebijakan lintas kementerian dan lembaga mengeluarkan berbagai kebijakan. Salah satu kebijakan pemerintah adalah revitalisasi pendidikan Indonesia. Dukungan dari pemerintah harus mencakup, 1) sistem pembelajaran, 2) satuan pendidikan, 3) peserta didik, dan 4) pendidik dan tenaga kependidikan juga dibutuhkan.

Revitalisasi sistem pembelajaran meliputi, 1) kurikulum dan pendidikan karakter, 2) bahan pembelajaran berbasis teknologi informasi dan komunikasi, 3) kewirausahaan, 4) penyelarasan, dan 5) evaluasi. Satuan pendidikan meliputi, 1) unit sekolah baru dan ruang kelas baru, 2) ruang belajar lainnya, 3) rehabilitasi ruang kelas, 4) asrama siswa dan guru, 5) peralatan, dan 6) manajemen dan kultur sekolah. Elemen peserta didik meliputi, 1) pemberian beasiswa dan 2) pengembangan bakat minat. Elemen pendidik dan tenaga kependidikan meliputi, 1) penyediaan, 2) distribusi, 3) kualifikasi, 4) sertifikasi, 5) pelatihan, 6) karir dan kesejahteraan, dan 7) penghargaan dan perlindungan (Muhammad, 2018).

Salah satu tuntutan revitalisasi
sistem kurikulum $\quad$ tersebut diimplementasikan oleh Kementerian Pendidikan dan Kebudayaan Republik Indonesia dengan cara mengembangkan kurikulum baru untuk Sekolah Dasar (SD), Sekolah Menengah Pertama (SMP), Sekolah Menengah Atas (SMA) dan Sekolah Menengah Kejuruan (SMK) yaitu kurikulum K13.
Kurikulum 2013 ini mengadaptasi konsep pendidikan abad 21. Kompetensi Abad 21 menuntut dunia pendidikan mengintegrasikan kecakapan pengetahuan, keterampilan, dan sikap, serta penguasaan terhadap Teknologi Informasi dan Komunikasi (TIK). Dunia pendidikan dituntut melahirkan peserta didik yang mampu menghadapi tantangan global. Tuntutan ini seiring dengan perkembangan pilar pendidikan yang dikembangkan oleh UNESCO, yaitu learning to know, learning to do, learning to be, dan learning to live together in peace.

Ada tiga subjek inti pendidikan abad 21, yaitu: 1) Life and Career Skills, 2) Learning and innovations Skills - 4Cs, 3) Information, Median and Technologi Skills. Bila konsep ini bisa dijalankan di sekolahsekolah dan para siswa Indonesia terbekali dengan keutamaan-keutamaan tersebut, yakni komunikasi, kolaborasi, berpikir kritis dan pemecahan masalah, serta kreatif dan inovatif, konsep yang baik, maka siswa siswi Indonesia akan mampu bersaing di abad ke 21 .

Namun tidak dapat dipungkiri bahwa sampai saat ini sebagian besar guru di Indonesia dalam pembelajaran masih sangat dominan menyampaikan pengetahuan faktual kepada siswa melalui ceramah dan buku teks. Model ini memang tampak sangat efektif karena materinya akan dapat selesai tepat waktu. Namun pembelajaran seperti ini hanya memberikan kesempatan kepada siswa untuk belajar informasi tetapi tidak memiliki banyak berlatih menerapkan pengetahuan untuk konteks yang baru, berkomunikasi dalam cara yang kompleks, menggunakannya untuk memecahkan masalah, atau menggunakannya sebagai platform untuk mengembangkan kreativitas yang merupakan ciri pengembangan keterampilan abad 21 .

Data hasil Programme for International Student Assesment (PISA), Trends in International Mathematics and Science Study (TIMSS), dalam tes IPA dan Matematika anak Indonesia hanya dapat mengerjakan tes dengan tingkat kesulitan di bawah level, satu sementara anak-anak Jepang dan Korea dapat 
mengerjakan tes dalam level 5-6, yakni level yang paling tinggi. Angka ini menunjukkan sebuah tantangan dari guru kita karena soal PISA lebih banyak problem solving dan critical thinking sedangkan pembelajaran kita lebih banyak pada hafalan, sehingga siswa kita sulit untuk menjawab soal, artinya tantangan bagi guru kita bagaimana meningkatkan kemampuan problem solving dan critical thinking pada siswa - siswa kita. Dari tahun 2007 hingga 2011 pencapaian anak-anak Indonesia dalam mengerjakan soal PISA selalu konsisten. Empat tahun kemudian walau ada perbaikan tetapi masih tetap belum mampu naik ke Level tinggi.

Penelitian tentang keterampilan berkolaborasi dan berkomunikasi yang dibutuhkan untuk dunia kerja juga dilaksanakan oleh Suvey of Adult Skills oleh OECD yang diselenggarakan di Jakarta pada 1 April 2014 sampai dengan 31 Maret 2015 dengan subyek penelitian sebanyak 50.250 orang dewasa berumur 16-65 th mengungkapkan bahwa penduduk dewasa di Jakarta mendapatkan skor antara 326-327 dari skor maksimal 500 pada kemampuan numerasi yang menyoroti pada aktivitas responden yang berupa keterampilan kolaborasi dan komunikasi yang dibutuhkan pada dunia kerja. Skor ini menunjukkan level yang masih rendah jika dibandingkan dibandingkan penduduk dewasa negara lain yang berpartisipasi dalam survey (OECD, 2016).

Menurut Menteri Tenaga Kerja dan Transmigrasi, Suparno (2008) menyatakan rendahnya mutu dan kompetensi SDM terindikasi dari kenyataan bahwa banyak kesempatan kerja, di dalam negeri hanya bisa terisi rata-rata nasional $30 \%$ sedangkan di luar negeri banyak lowongan pekerjaan (labour skills) yang tidak terisi, hal ini disebabkan karena rendahnya mutu dan kompetensi SDM tidak mampu memenuhi kriteria atau kebutuhan pasar kerja, baik di dalam maupun di luar negeri. Kebutuhan pasar kerja pada era saat ini adalah mengikuti tuntutan dunia kerja abad 21 yang diantaranya adalah tuntutan dalam hal keterampilan kolaborasi dan keterampilan komunikasi. Keterampilan kolaborasi dan keterampilan komunikasi pekerja di Indonesia terindikasi masih rendah. Berbagai temuan empiris yang telah dipaparkan sebelumnya merupakan indikasi bahwa keterampilan berpikir kritis dan pemecahan masalah, keterampilan berkomunikasi dan berkolaborasi pada anak- anak usia sekolah dan usia pekerja masih dibilang rendah.

Untuk mendapatkan data tentang keterampilan belajar dan berinovasi pada siswa SD, maka diperlukan sebuah instrumen asessmen yang valid dan reliabel yang mampu menilai keterampilan belajar dan berinovasi siswa SD. Pengukuran keterampilan berinovasi sebenarnya telah dikembangkan untuk karyawan di tempat kerjanya oleh The Conference Board of Canada (2013) yang dikenal sebagai General Innovation Skill Aptitude Test 2.0 (GISAT 2.0). Pengukuran keterampilan berinovasi ini terdiri dari 4 pilar yaitu: (1) keterampilan berkreativitas, pemecahan masalah dan perbaikan berkelanjutan (creativity, problem solving, and continous improvement skills), (2) mengambil resiko terhitung dan menjadi entrepreneur (taking calculated risks and being entrepreneural), (3) mengembangkan dan mempertahankan hubungan interpersonal (developing and maintaining interpersonal relationships), dan (4) mewujudkan gagasan-gagasan menjadi produk, proses, dan layanan (turning ideas into products, processes, and services). Tiap-tiap pilar diukur dalam dua matra yaitu: (a) berbuat dan berkontribusi (act and contribute), dan (b) mengelola dan mendukung orang lain (manage and support others). Namun instrumen ini digunakan untuk mengetes karyawan perusahaan. Tes ini diadopsi dalam menyiapkan SDM bermutu untuk menghadapi abad industri 4.0.

Tes kemampuan berkolaborasi dari International Reading Association (IRA) yang memiliki aspek kontribusi (Contributions), manajemen waktu (Time management), pemecahan masalah (Problem solving), bekerja dengan orang lain (Working with others), teknik penyelidikan (Research techniques) dan sintesis (Synthesis) (Read Write Think, 
2005) hanya terdapat rubrik penilaiannya, sehingga perlu dibuatkan instrumen asesmennya yang berupa lembar observasi. Begitu juga untuk keterampilan berkomunikasi, hanya terdapat rubrik dan akan dikembangkan dan disesuaikan untuk pembelajaran anak SD.

Sehingga penelitian ini nantinya diharapkan mampu menghasilkan instrumen asesmen keterampilan belajar dan berinovasi pada siswa SD khususnya mata pelajaran IPA yang memenuhi kriteria valid secara isi dan konstruk serta reliabel guna mengukur keterampilan belajar dan berinovasi siswa SD. Pemilihan mata pelajaran IPA sendiri didasarkan atas peranan IPA sebagai bekal bagi peserta didik dalam menghadapi berbagai tantangan di era global, menyiapkan peserta didik untuk memiliki kompetensi yang baik dan melek sains serta teknologi, mampu berpikir logis, kritis, kreatif, berargumentasi secara benar, dapat berkomunikasi serta berkolaborasi.

Harapan dengan hasil asesmen nantinya dapat digunakan sebagai dasar dalam pengambilan berbagai keputusan tentang siswa, proses pembelajaran, kurikulum dan kebijakan pendidikan serta sebagai upaya membangun pendidikan bermutu dan bermakna, hasil penilaian menjadi dasar dalam perumusan kebijakan pembangunan dan perbaikan mutu pendidikan.

Adapun tujuan dari penelitian ini adalah: (1) mengetahui kebutuhan terhadap instrumen asesmen keterampilan belajar dan berinovasi pada mata pelajaran IPA SD. (2) mengetahui design instrumen asesmen keterampilan belajar dan berinovasi pada mata pelajaran IPA SD. (3) mengetahui kualitas instrumen asesmen keterampilan belajar dan berinovasi pada mata pelajaran IPA SD hasil pengembangan dari aspek validitas, reliabilitas dan kepraktisan.

\section{METODE PENELITIAN}

Pengembangan

asesmen keterampilan belajar dan berinovasi pada penelitian ini diadaptasi dari model 4-D yang dikembangkan oleh Thiagarajan (1974). Pengembangannya terdiri dari empat tahap yaitu define, design, develop dan disseminate.

Pada tahap define (pendefinisian), kegiatannya adalah menetapkan dan mendefenisikan syarat-syarat pengembangan. Secara umum, dalam pendefenisian ini dilakukan kegiatan analisis kebutuhan pengembangan, syarat-syarat pengembangan produk yang sesuai dengan kebutuhan pengguna serta model penelitian dan pengembangan (model R \& D) yang cocok digunakan untuk mengembangkan model. Tahap design mensimulasikan instrumen asesmen keterampilan belajar dan berinovasi. Dalam tahap develop dilakukan evaluasi oleh ahli dalam bidangnya. Saran-saran yang diberikan digunakan untuk memperbaiki instrumen asesmen. Pada konteks pengembangan model pembelajaran, tahap dessemination dilaksanakan uji coba instrumen di kelas terbatas.

Penelitian ini dilaksanakan di seluruh sekolah dasar gugus 6 Kecamatan Banjar Buleleng Bali. Khusunya di kelas $\mathrm{V}$ SD, dengan total objek 6 orang guru SD dan 107 siswa kelas 5 SD. Jenis data yang dibutuhkan dalam pengembangan instrumen asesmen keterampilan belajar dan berinovasi berupa data kualitatif dan data kuantitatif. Data analisis kebutuhan instrumen asesmen berupa data kualitatif dan data kuantitatif yang diperoleh melalui observasi dan wawancara, data mengenai design instrumen asesmen diperoleh melalui masukan dari para ahli, terakhir data mengenai kualitas instrumen diperoleh melalui uji coba pada kelas terbatas menggunakan tes uraian dan lembar observasi.

\section{HASIL DAN PEMBAHASAN}

Penelitian ini telah melalui beberapa tahap pengembangan instrumen. Setiap tahap diperoleh beberapa temuan. Adapun temuan tersebut dapat dijelaskan sesuai tahapan yang dilalui, yakni Tahap Define, Design, Develop, dan Disseminate.

\section{Tahap Define,}

Pada tahap ini diperoleh data tentang analisis kebutuhan terhadap 
instrumen asesmen keterampilan belajar dan berinovasi pada mata pelajaran IPA SD. Fungsi analisis kebutuhan pembelajaran menurut Morison (dalam Warsita, 2011): a) Mengidentifikasi kebutuhan yang relevan dengan pekerjaan atau tugas sekarang, yaitu masalah yang mempengaruhi hasil pembelajaran. b) Mengidentifikasi kebutuhan mendesak yang terkait dengan finansial, keamanan atau masalah-masalah lain yang menggangu pekerjaan atau lingkungan pendidikan c) Menyajikan skala prioritas untuk memilih tindakan yang tepat dalam mengatatasi masalah-masalah pembelajaran. d) Memberikan data basis untuk menganalisis efektifitas kegiatan pembelajaran.

Hasil observasi menyatakan sekolah yang dipilih sebagai tempat penelitian sudah memberlakukan kurikulum 2013 yang artinya sudah mengimplementasikan 3 konsep pendidikan abad 21 (ketrampilan dan pengetahuan abad 21 , pendekatan saintifik, dan penilaian autentik). Materi pelajaran IPA SD kelas $\mathrm{V}$ adalah organ gerak hewan dan tumbuhan, udara bersih bagi kesehatan, makanan sehat, ekosistem, panas dan perpindahannya, lingkungan dan benda di sekitar kita.

Hasil wawancara dengan guru diperoleh data aspek pengalaman 100\% guru pernah mendengar istilah keterampilan belajar dan berinovasi namun hanya $66 \%$ yang mampu menyebutkan bagian- bagian dari keterampilan belajar dan berinovasi. Sedangkan aspek pengalaman pada siswa $33 \%$ sudah mengenal istilah keterampilan belajar dan berinovasi dan hampir $100 \%$ siswa menyatakan belum pernah diberikan soal yang mengukur keterampilan belajar dan berinovasinya. Jadi secara umum guru dan siswa sudah memiliki pengalaman tentang keterampilan belajar dan berinovasi, meskipun pengalaman yang dimiliki hanya sebatas mendengar keterampilan belajar dan berinovasi. Sedangkan untuk pengalaman siswa mengerjakan soal- soal yang berhubungan dengan keterampilan belajar dan berinovasi masih sangat kurang, hal ini tidak terlepas dari peranan guru di sekolah dalam pelaksanaan pembelajaran.

Selanjutnya hasil analisis kebutuhan pada aspek psikologis sebanyak $50 \%$ guru tertarik dan termotivasi membuat soal keterampilan belajar dan berinovasi. Aspek psikologis pada siswa sebesar 93\% siswa tertarik mengetahui tes keterampilan belajar dan berinovasi serta sebanyak $86 \%$ siswa bersedia jika diberikan soal yang mengukur keterampilan belajar dan berinovasi. Sehingga baik guru maupun siswa secara psikologis tertarik dan termotivasi untuk mengukur keterampilan belajar dan berinovasinya. Siswa yang memiliki motivasi dalam belajar, yakni keadaan atau kondisi siswa yang bersemangat dalam belajar biasanya didukung oleh kondisi atau lingkungan yang peduli terhadap perkembangan belajar siswa.

Pada aspek kemampuan sebanyak sebanyak $50 \%$ orang guru memahami salah satu tes keterampilan belajar dan berinovasi dan menyatakan mampu mengerjakan soal keterampilan belajar dan berinovasi. Sedangkan pada siswa sebesar $66 \%$ menyatakan mampu mengerjakan salah satu tes keterampilan belajar dan berinovasi.

Dari data di atas sebenarnya sudah terjadi sedikit kesenjangan antara tujuan implementasi kurikulum 2013 dengan kenyataan yang ada di lapangan. Guru dan siswa hanya pernah mendengar keterampilan belajar dan berinovasi, tanpa mereka paham apa sebenarnya keterampilan belajar dan berinovasi tersebut. Padahal seperti yang kita ketahui, keterampilan belajar dan berinovasi merupakan bagian dari kurikulum 2013, yang semestinya sudah dimasukan ke dalam rencana pelaksanaan pembelajaran dan dilaksanakan pada saat pembelajaran seperti pemberian soal-soal HOTS atau penilaian yang mengukur ketrampilan itu sendiri.

Dalam menjalankan kurikulum 2013 yang menuntut pendekatan scientific yang di dalamnya memuat student center, maka guru diwajibkan mengarahkan siswa untuk menguasai kemampuan berpikir tingkat tinggi yaitu kemampuan penguasaan 
materi dengan praktiknya yang seimbang. Ketika guru tidak mampu mengarahkan siswanya untuk menguasai kemampuan tingkat tinggi, maka dapat dibayangkan output dari sekolah tersebut tidak akan menghasilkan peserta didik yang berkompeten dan mampu bersaing seperti harapan pendidikan abad 21 .

Maka guru adalah faktor penentu keberhasilan proses pembelajaran yang berkualitas. Sehingga berhasil tidaknya pendidikan mencapai tujuan selalu dihubungkan dengan kualitas para guru. Oleh karena itu, usaha-usaha yang dilakukan dalam meningkatkan mutu pendidikan hendaknya dimulai dari peningkatan kualitas guru. Guru yang berkualitas diantaranya adalah mengetahui dan mengerti peran dan fungsinya dalam proses pembelajaran. Guru yang berkualitas selalu fleksibel mengikuti perkembangan kurikulum dan selalu terdepan dalam menyerap maupun mengimplementasikan berbagai informasiinformasi baru kepada siswanya.

Guru memikul tanggung jawab utama dalam transformasi orientasi peserta didik dari ketidaktahuan menjadi tahu, dari ketergantungan menjadi mandiri, dari tidak terampil menjadi terampil, dengan metode-metode pembelajaran bukan lagi mempersiapkan peserta didik yang pasif, melainkan peserta didik berpengetahuan yang senantiasa mampu menyerap dan menyesuaikan diri dengan informasi baru dengan berpikir, bertanya, menggali, mencipta dan mengembangkan cara-cara tertentu dalam memecahkan masalah yang berkaitan dengan kehidupannya.

Perubahan ini penting untuk memunculkan bentuk-bentuk pembelajaran baru yang dibutuhkan dalam mengatasi tantangan global yang kompleks. Standar baru diperlukan agar siswa kelak memiliki kompetensi yang diperlukan pada abad ke-21. Sekolah ditantang menemukan cara dalam rangka memungkinkan siswa sukses dalam pekerjaan dan kehidupan melalui penguasaan keterampilan berpikir kreatif, pemecahan masalah yang fleksibel, berkolaborasi dan berinovasi.
Terkait dengan Kurikulum 2013 terdapat beberapa hal yang perlu diperhatikan di dalam implementasinya. Permendikbud No. 65 Tahun 2013 menyebutkan terdapat 4 komponen yang perlu diperhatikan seperti (a) mempersiapkan proses pengajaran dan pembelajaran, (b) melaksanakan pengajaran dan pembelajaran, (c) mengevaluasi dan melaksanakan asesmen terhadap proses pembelajaran, dan (d) membantu proses pembelajaran. Keempat komponen tersebut harus diintegrasikan di dalam pengimplementasian Kurikulum 2013 yang wajib dilaksanakan oleh guru (Marhaeni, 2017).

Menggunakan berbagai bentuk asesmen maka dapat mengetahui proses pembelajaran siswa, sikap, kebiasaan, dan hal-hal lainnya terkait dengan pembelajaran siswa. Jadi dengan menggunakan instrumen asesmen keterampilan belajar dan berinovasi maka akan dapat mengetahui kognitif siswa maupun sikap siswa. Serta dapat mengetahui sejauh mana ketercapaian implementasi kurikulum 2013.

\section{Tahap Design}

Pada tahap Design, dilakukan perancangan instrumen dengan mengacu pada kriteria secara kualitatif maupun secara kuantitatif guna mendapatkan design instrumen keterampilan belajar dan berinovasi yang baik dan benar.

Langkah pertama yang dilaksanakan adalah menentukan tes acuan patokan yang disusun berdasarkan spesifikasi tujuan pembelajaran dan analisis siswa, kemudian selanjutnya disusun kisi-kisi tes. Kisi-kisi adalah suatu format atau matriks yang memuat kriteria tentang soal-soal yang diperlukan atau yang hendak disusun. Kisi-kisi juga dapat diartikan test blue-print atau table of specification yang merupakan deskripsi kompetensi dan materi yang akan diujikan. Wujudnya adalah sebuah tabel yang memuat tentang perperincian materi dan tingkah laku beserta imbangan/proporsi yang dikehendaki oleh penilai. Tiap kotak diisi dengan bilangan yang menunjukkan jumlah soal (Arikunto, 2007). Tujuan 
penyusunan kisi-kisi adalah untuk menentukan ruang lingkup dan sebagai petunjuk dalam menulis soal

Kisi-kisi dibuat dengan matriks yang terdiri dari dua jalur, yaitu kolom dan baris. Kisi-kisi adalah format yang berupa matriks yang memuat informasi tentang suatu soal dan dijadikan pedoman untuk menulis soal atau merakit soal menjadi seperangkat tes. Dengan demikian jelas bahwa fungsi kisi-kisi di sini adalah sebagai pedoman dalam penulisan dan perakitan tes. Kisi-kisi yang baik harus memenuhi persyaratan: (1) mewakili isi kurikulum yang akan diujikan, (2) komponen-komponennya rinci, jelas, dan mudah dipahami, (3) soal-soal yang direncanakan dimungkinkan dapat dibuat sesuai dengan indikator yang direncanakan dalam kisi-kisi itu.

Keterampilan berpikir kritis terdiri dari 6 aspek dan setiap aspek terdiri dari beberapa indikator, setiap indikator terdapat soal yang disesuaikan dengan materi pelajaran IPA kelas $\mathrm{V}$ SD. Keterampilan pemecahan masalah terdiri dari 4 aspek, dan setiap aspek dibuatkan soal, total jumlah soal pemecahan masalah sebanyak 8 soal. Instrumen kreativitas siswa terdiri 5 aspek, setiap aspek terdapat beberapa indikator. Total soal kemampuan berpikir kreatif adalah 10 soal. Keterampilan berkolaborasi, terdiri dari 6 aspek, dan masing- masing aspek dibuatkan pernyataan. Total pernyataan keterampilan berkolaborasi adalah 18 pernyataan. Keterampilan berkomunikasi, terdiri dari 6 aspek, dan masing- masing aspek dibuatkan pernyataan. Total pernyataan keterampilan berkomunikasi adalah 18 pernyataan.

Untuk tes berpikir kritis dan mengatasi masalah dan kreativitas menggunakan tes non objektif atau disebut pula sebagai soal uraian. Tes uraian dipilih karena dapat mengembangkan kemampuan berpikir tingkat tinggi. Dalam tes uraian (nonobjektif) ini siswa seringkali diminta untuk mengorganisasikan jawaban pertanyaannya dalam bentuk baru atau bahasanya sendiri. Sedangkan keterampilan berkolaborasi dan keterampilan berkomunikasi menggunakan menggunakan non tes berupa lembar observasi.

Seperti pada tes lain, untuk mendapatkan soal tes uraian yang baik, perlu direncanakan secara matang. Paling tidak peneliti yang membuat soal harus memahami atau mengingat kembali prinsip-prinsip penilaian, dan mengingat kembali prosedur pengembangan tes secara umum. Secara umum perencanaan itu mencakup: (1) Merumuskan tujuan tes, untuk apa tes itu dilakukan. (2) Mengkaji/menganalisis: pokok bahasan/topik/tema/konsep, buku sumber, rencana pembelajaran/satuan pelajaran, dan materi-materi pelajaran mana yang cocok untuk dibuat dengan soal uraian. (3) Membuat kisi-kisi (4) Penulisan soal disertai pembuatan kunci jawaban dan pedoman penskoran (5) Penelaahan kembali rumusan soal (oleh sendiri atau orang lain).

Dalam menulis soal bentuk uraian, penulis soal harus mempunyai gambaran tentang ruang lingkup materi yang ditanyakan dan lingkup jawaban yang diharapkan, kedalaman dan panjang jawaban, atau rincian jawaban yang mungkin diberikan oleh siswa. Dengan adanya batasan ruang lingkup, kemungkinan terjadinya ketidakjelasan soal dapat dihindari, serta dapat mempermudah pembuatan kriteria atau pedoman penyekoran. Karena itu kaidah umum yang terpenting dalam menulis soal bentuk uraian adalah, segera tulis kunci jawaban atau pokok-pokok jawaban yang mungkin diberikan oleh siswa beserta kriteria atau rentang skor yang mungkin diberikan, begitu selesai menulis soal.

Kaidah khusus penulisan soal bentuk uraian adalah menetapkan kriteria tes yang baik secara kuantitatif, peneliti melakukan kajian beberapa literatur. Yang dimaksud dengan persyaratan kualitatif dalam menyusun soal uadalah aspek substantive (materi), aspek konstruksi, dan aspek bahasa. Secara kuantitaif, instrumen yang dirancang perlu memenuhi kriteria tes yang baik berdasarkan parameter-parameter butir soal.

Parameter-parameter butir soal berbentuk uraian ada dua, yaitu tingkat kesukaran dan daya beda. Meskipun 
seluruh soal sudah di uji tingkat ke validan dan tingkat reliabilitas nya, bukan berarti soal sudah layak pakai, karena kita tidak tahu bagian soal mana yang sudah dirasa pernah dipelajari dan juga bagian soal mana yang tergolong mudah maupun sulit, yang mana hal tersebut mempengaruhi terhadap kualitas soal. Oleh karena itu, tentunya tujuan analisis uji daya pembeda dan tingkat kesukaran sangat diperlukan. Menganalisis tingkat kesukaran soal artinya mengkaji soal- soal tes dari segi kesulitanya sehingga dapat di peroleh soal-soal mana yang termasuk mudah, sedang dan sukar. Sedangkan menganalisis daya pembeda artinya mengkaji soal-soal tes dari segi kesanggupan tes tersebut dalam kategori lemah atau rendah dan kategori kuat atau tinggi prestasinya (Nurkancana, 1983).

\section{Tahap Develop}

Pada tahap develop, langkah yang dilakukan adalah membuat instrumen (constructing test) dan validasi isi oleh pakar (expert appraisal).

Validasi instrumen keterampilan belajar dan berinovasi meliputi validitas isi dan validitas butir instrumen. Validitas isi dilakukan oleh dua orang pakar ahli pendidikan. Dalam Standar untuk Tes Pendidikan dan Psikologi (American Educational Research Association, American Psychological Association \& National Council of Measurement in Education, 1985) "bukti validitas terkait konten" didefinisikan sebagai "bukti yang menunjukkan sejauh mana isi tes sesuai dengan tujuan yang dimaksudkannya. Bukti tersebut digunakan untuk menetapkan bahwa pengujian tersebut mencakup contoh yang representatif atau kritis dari domain konten yang relevan dan isinya tidak termasuk konten di luar domain tersebut". Validitas isi merupakan validitas yang diestimasi lewat pengujian terhadap kelayakan atau relevansi isi tes melalui analisis rasional oleh panel yang berkompeten atau melalui expert judgement (penilaian ahli). Validitas isi atau content validity memastikan bahwa pengukuran memasukkan sekumpulan item yang memadai dan mewakili yang mengungkap konsep. Semakin item skala mencerminkan kawasan atau keseluruh konsep yang diukur, semakin besar validitas isi. Atau dengan kata lain, validitas isi merupakan fungsi seberapa baik dimensi dan elemen sebuah konsep yang telah digambarkan (Sekaran, 2006).

Hasil validitas pakar I dan pakar II adalah tes keterampilan berpikir kritis dan tes pemecahan masalah berada pada kategori tinggi sebesar 0,7. Tes kreativitas berada pada kategori tinggi sebesar 0,8. Tes ketrampilan berkolaborasi berada pada kategori tinggi sebesar 0,7. Dan tes ketrampilan berkomunikasi berada pada kategori tinggi sebesar 0,6. Sedangkan hasil validasi isi instrumen dari para praktisi memperoleh skor 12 dan berada pada kategori valid, hasil validasi aspek konstruksi memperoleh skor 10,6 dan berada pada kategori valid. Dan yang terakhir hasil validasi aspek bahasa berada memperoleh skor 9,8 berada pada kategori valid. Secara umum kesimpulan hasil uji validasi isi instrumen dari para ahli dan praktisi yaitu valid sehingga bisa dikatakan bahwa faktor-faktor yang merupakan bagian dari instrumen tersebut tidak meyimpang dari fungsi instrumen.

\section{Tahap Disseminate.}

Pada tahap ini, peneliti melaksanakan uji coba butir instrumen. Dantes (2012) menyatakan bahwa pengujian butir tes dimaksudkan untuk menilai kemampuan tiap-tiap butir. Dengan pengujian ini maka dapat dibuktikan secara empirik apakah butir tes tersebut baik atau tidak.

Uji validitas butir instrumen asesmen keterampilan belajar dan berinovasi yang menggunakan sampel sebanyak 107 siswa yang dianalisis menggunakan program Microsoft Excel. Hasil validitas butir keterampilan berpikir kritis, terdapat 3 soal yang tidak valid yaitu soal no 9, 10, 12 sehingga soal tersebut tidak digunakan. Hasil validitas keterampilan pemecahan masalah tidak terdapat soal yang tidak valid, sehingga semua soal digunakan. Hasil validitas tes kreativitas terdapat satu soal yang tdak valid yaitu soal no 7. Hasil validitas keterampilan berkolaborasi terdapat dua soal yang tidak valid, sehingga tidak digunakan dan yang 
terakhir hasil validitas ketrampilan berkomunikasi terdapat dua soal yang tidak valid yaitu soal no 7 dan 11 .

Setelah melaksanakan uji validitas butir insrumen, langkah selanjutnya adalah melaksanakan uji reliabilitas tes instrumen. Hasil uji reliabilitas keterampilan berpikir kritis memperoleh hasil $r 11$ sebesar 0,45 yang berkategori sedang. Hasil uji reliabilitas keterampilan pemecahan masalah memperoleh $\mathrm{r} 11$ sebesar 0,55 yang berkatagori sedang. Hasil uji reliabilitas tes kreativitas memperoleh hasil $r 11$ sebesar 0,63 yang berkategori tinggi. Hasil uji keterampilan berkolaborasi dan keterampilan berkomunikasi memperoleh $\mathrm{r} 11$ sebesar 0,49 dan 0,45 yang berkatagori sedang.

Instrumen tes keterampilan berpikir kritis, tes keterampilan pemecahan masalah dan tes kreativitas siswa akan dilanjutkan ke uji tingkat kesukaran tes dan daya beda tes. Sedangkan keterampilan berkolaborasi dan keterampilan berkomunikasi merupakan lembar observasi maka tidak dilanjutkan ke uji tingkat kesukaran tes dan daya beda. Hasil uji daya beda tes sebagian besar masuk dalam kategori cukup, hanya satu soal tes keterampilan berpikir kritis yang memperoleh hasil uji daya beda sebesar 0.4 yang masuk kategori baik. Daya beda soal adalah kemampuan suatu soal untuk membedakan atara peserta didik yang sudah menguasai materi, dan peserta didik yang belum menguasai materi kompetensi dasar (Kunandar, 2014). Jadi kesimpulannya adalah tes keterampilan berpikir kritis, tes keterampilan pemecahan masalah dan tes kreativitas siswa cukup membedakan siswa yang tergolong mampu (tinggi prestasinya) dengan siswa yang tergolong kurang atau lemah prestasinya

Hasil uji tingkat kesukaran tes ketrampilan berpikir terdapat 2 soal yaitu no 5 dan 9 masuk dalam kategori sukar, sedangkan soal lainnya berkategori sedang. Hasil uji tes ketrampilan pemecahan masalah terdapat 2 doal yang berkatagori sukar yaitu soal no 3 dan 5 sedangkan soal lainnya berkategori sedang. Tes hasil uji tingkat kesukaran kreativitas terdapat 3 soal yang berkatagori sukar, yaitu soal number 3.5 dan 8 sedangkan soal lainnya berkategori sedang.

Ada beberapa dasar pertimbangan dalam menentukan proporsi jumlah soal kategori mudah sedang dan sukar. Pertimbangan pertama adalah adanya keseimbangan, yakni jumlah soal sama untuk ke tiga kategori tersebut. dan ke dua proposi jumlah soal untuk ke tiga kategori tersebut artinya sebagian besar soal berada dalam kategori sedang sebagian lagi termasuk kategori mudah dan sukar dengan proporsi yang seimbang. Perbandingan antara soal mudah sedang sukar bisa di buat 3-4-3. Artinya, 30\% soal kategori mudah $40 \%$ soal kategori sedang dan $30 \%$ lagi soal kategori sukar. Jadi instrumen berpikir kritis, pemecahan masalah dan kreativitas belum memenuhi aturan perbandingan tingkat kesukaran soal, karena instrumen berpikir kritis, pemecahan masalah dan kreativitas hanya berada pada kategori sedang dan sukar, tidak terdapat soal yang berkatagori mudah.

Hasil uji kepraktisan instrumen asesmen keterampilan belajar dan berinovasi dinilai dari respon guru dan siswa terhadap instrumen asesmen keterampilan belajar dan berinovasi. hasil respon guru terhadap keterlaksanaan instrumen asesmen keterampilan belajar dan berinovasi adalah sangat praktis pada aspek afektif dan praktis pada aspek interaktif, menarik, efisien dan kreatif. Sedangkan hasil respon siswa terhadap keterlaksanaan instrumen asesmen keterampilan belajar dan berinovasi adalah praktis pada semua aspek yaitu aspek afektif, interaktif, menarik, efisien dan kreatif. Arikunto (2010) mengartikan kepraktisan dalam evaluasi pendidikan merupakan kemudahan-kemudahan yang ada pada instrument evaluasi baik dalam mempersiapkan, menggunakan, menginterpretasi/ memperoleh hasil, maupun kemudahan dalam menyimpanya.

Kepraktisan sebuah alat evaluasi lebih menekankan pada tingkat efisiensi dan efektivitas alat evaluasi tersebut, beberapa kriteria yang dikemukakan oleh Gerson, dkk dalam mengukur tingkat kepraktisan, diantaranya adalah: 
Waktu yang diperlukan untuk menyusun tes tersebut. (b) Biaya yang diperlukan untuk menyelenggarakan tes tersebut. (c) Waktu yang diperlukan untuk melaksanakan tes (d) Tingkat kesulitas menyusun tes (e) Tingkat kesulitan dalam proses pemeriksaan tes (f) Tingkat kesulitan melakukan intrepetasi terhadap hasil tes

\section{SIMPULAN DAN SARAN}

Berdasarkan hasil analisis data dan pembahasan dapat dikemukakan temuan-temuan sebagai berikut.

1. Instrumen keterampilan belajar dan berinovasi sangat dibutuhkan oleh siswa SD Hal ini dikarenakan kegiatan asesmen sangat penting dalam pembelajaran untuk mengetahui sejauh mana keterampilan belajar dan berinovasi peserta didik.

2. Design instrumen asesmen keterampilan belajar dan berinovasi pada mata pelajaran IPA SD mengacu pada kriteria secara kualitatif maupun secara kuantitatif. Ketrampilan berpikir kritis, pemecahan msalah dan kreativitas siswa berupa tes uraian, sedangkan keterampilan berkomunikasi dan keterampilan berkolaborasi berupa lembar observasi.

3. Kualitas Instrumen Asesmen Keterampilan Belajar dan Berinovasi pada Mata Pelajaran IPA SD Hasil Pengembangan sudah memenuhi dari Aspek Validitas, Reliabilitas dan Kepraktisan.

Adapun saran yang disampaikan dalam penelitian pengembangan instrumen asesmen keterampilan belajar dan berinovasi ini,

1. Saran pemanfaatan untuk guru, disarankan untuk memanfaatkan instrumen asesmen keterampilan belajar dan berinovasi sebagai alat penilaian dalam proses pembelajaran kepada siswanya dan memanfaatkan instrumen asesmen keterampilan belajar dan berinovasi ini untuk mengembangkan hasil belajar siswa pada pelajaran IPA serta pada penilaian presentasi menggunakan instrumen berkomunikasi dan pada penilaian kerja kelompok menggunakan instrusmen berkolaborasi.

2. Saran desiminasi, disarankan untuk menyebarluaskan produk di sekolah dengan menyerahkan instrumen asesmen keterampilan belajar dan berinovasi dan panduan penggunaan instrumen asesmen keterampilan belajar dan berinovasi kepada guru di tempat uji produk serta menyebarluaskan melalui publikasi jurnal.

3. Saran pengembangan produk lebih lanjut, disarankan untuk mengembangkan instrumen asesmen keterampilan belajar dan berinovasi pada materi lain, mata pelajaran lain dan kelas yang berbeda.

\section{DAFTAR RUJUKAN}

Arikunto, S. 2010. Prosedur Penelitian Suatu Pendekatan Praktik. Jakarta:Rineka Cipta.

Dantes, N. 2012. Metode Penelitian. Yogyakarta: ANDI

General Innovation Skills Aptitude Test 2.0. A product of The Conference Board of Canada's Centre for Business Innovation. The Conference Board of Canada, 2013.

Kunandar, 2014. Penilaian Autentik (Penilaian Hasil Belajar Peserta Didik Berdasarkan Kurikulum 2013). Jakarta: Raja Grafindo Persada.

Marhaeni, A. A. I. N., \& Kusuma, I. P. I. 2017. Analisis Implementasi Asesmen Autentik pada Pembelajaran Bahasa Inggris dalam Implementasi Kurikulum 2013 di SMA di Bali. In Seminar Nasional Riset Inovatif ,5: 555-561. 
Nurkancana W. 1983. Evaluasi Pendidikan. Surabaya: Usaha Nasional.

OECD. 2003. The PISA 2003 Assessment Framework. Paris: OECD.

(http://www.businessinsider.co.id/pi sa-worldwide-ranking-of-mathscience-reading-skills-2004-12/). Di download pada tanggal 21 Januari 2019

OECD. 2015. PISA 2015 Results. OECD. (http://www.businessinsider.co.id/pi sa-worldwide-ranking-of-mathscience-reading-skills-2016-12/). Di download pada tanggal 21 Januari 2019

Read Write Read Write Think 2005, Collaborative Work Skills Rubric, International Reading Association/Ncte.

Sekaran, U. 2006. Metodologi Penelitian Untuk Bisnis, Edisi Keempat.Jakarta: Salemba Empat.

Thiagarajan, S; Semmel, D.S; \& Semmel, M.I. $1974 . \quad$ Instructional Development for Training Teachers of Exceptional Children: A Sourcebook. Indiana: Indiana University.

Warsita, B. 2011. Modul: 01 Analisis Kebutuhan Sistem Pembelajaran, Kementerian Pendidikan dan Kebudayaan. Jakarta

Yahya, M. 2018. Era Industri 4.0 Tantangan dan Peluang Perkembangan Pendidikan Kejuruan Indonesia. Disampaikan pada Sidang Terbuka Luar Biasa Senat Tanggal 14 Maret 2018 